\title{
THE ROLE OF CATALYST PRECURSOR ANIONS IN COAL GASIFICATION
}

\author{
Second Quarterly Report \\ for the Period \\ January 1, 1992 - March 31, 1992
}

Godfried M.K. Abotsi

Principal Investigator

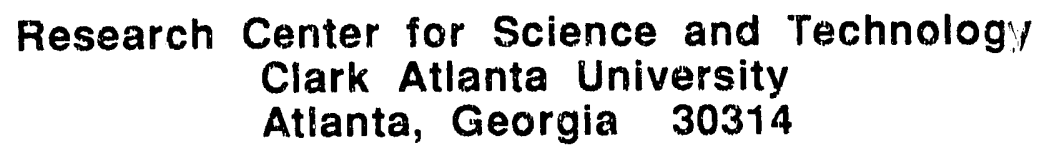

PREPARED FOR

UNITED STATES DEPARTMENT OF ENERGY UNDER CONTRACT NO. DE-FG22-91PC91286 


\title{
DISTRIBUTION
}

Dr. Jagdish L. Malhotra

U.S. Department of Energy

Morgantown Energy Technology Center

P. O. Box 880

Morgantown, WV 26505

Marilyn Keane

PM-40, MS922-206

U.S. Department of Energy

Pittsburgh Energy Technology Center

P. O. Box 10940

Pittsburgh, PA 15236

Cynthia Y. Mitchell

Contract Specialist

AD-22, 921-165

U.S. Department of Energy

Pittsburgh Energy Technology Center

P. O. Box 10940

Pittsburgh, PA 15236

\author{
Kay Downey \\ Office of Technology Transfer \\ U.S. Department of Energy \\ Pittsburgh Energy Technology Center \\ P. O. Box 10940 \\ Pittsburgh, PA 15236
}

\section{DISCLAIMER}

\begin{abstract}
This report was prepared as an account of work sponsored by an agency of the United States Government. Neither the United States Government nor any agency thereof, nor any of their employees, makes any warranty, express or implied, or assumes any legal liability or responsibility for the accuracy, completeness, or usefulness of any information, apparatus, product, or prosess disclosed, or represents that its use would not infringe privately owned rights. Reference herein to any specific commercial product, process, or service by trade name, trademark, manufacturer, or otherwise does not necessarily constitute or imply its endorsement, recommendation, or favoring by the United States Government or any agency thereof. The views and opinions of authors expressed herein do not necessarily state or reflect those of the United States Government or any agency thereof.
\end{abstract}




\begin{abstract}
The aims of the proposed project are to enrich our understanding of the roles of various aqueous soluble catalyst precursor anions on the surface electrical properties of coal and to ascertain the influence of the surface charge on the adsorption, dispersion, and activities of calcium and potassium. These goals will be achieved by impregnating a lignite and its demineralized derivative with calcium or potassium catalyst precursors containing acetate $\left.\left(\mathrm{CH}_{3} \mathrm{COO}\right)^{-}\right)$, chloride $(\mathrm{Cl})$, nitrate $\left(\mathrm{NO}_{3}{ }^{-}\right)$, sulfate $\left(\mathrm{SO}_{4}{ }^{2-}\right)$, and carbonate $\left(\mathrm{CO}_{3}{ }^{2-}\right)$ anions. Catalyst loading will be conducted under well-controlled conditions of solution $\mathrm{pH}$ and ionic strength.

Zeta potential measurements on a North Dakota lignite (PSOC 1482) as a function of acetate $\left(\mathrm{CH}_{3} \mathrm{COO}-\right)$ or nitrate $\left(\mathrm{NO}_{3}{ }^{-}\right)$concentration have shown that the surface charge density on the coal particles becomes less negative as the anion concentration is increased. For instance, at $\mathrm{pH} 9$ the zeta potential of the raw coal is $-72 \mathrm{mV}$ but decreased to about $-50,-10$ and $-2 \mathrm{mV}$ for $\mathrm{CH}_{3} \mathrm{COO}$ - concentrations of $10^{-3}, 10^{-2}$ and $10^{-1} \mathrm{~mol} 1^{-1}$, respectively. This trend suggests that the surface charge density of the coal is controlled by the adsorption of calcium ions $\left(\mathrm{Ca}^{2+}\right)$ onto the coal particles. The net negative charge on the coal particles creates a repulsive force between the anions and the coal surface and prevents the anions from exerting any effect on the coal's electrokinetic properties.
\end{abstract}




\section{INTRODUCTION}

Coal gasification activity is generally attributed to the metal components of catalyst precursors. However, there is evidence that the anion of the catalytic salt plays a significant role in the performance of the catalyst. It has been reported (1) that for the same metal, the chlorides, acetates, and hydroxides of sodium, potassium, magnesium, and calcium exhibited different char reactivities. The catalysts were loaded from aqueous solution. For example, at $1223 \mathrm{~K}$, the order of reactivity for the sodium compounds was $\mathrm{NaOH}>\mathrm{NaAc}>\mathrm{NaCl}$. These finding were rationalized in terms of the influence of the various anions on the diffusivities of the cations $\left(\mathrm{Na}^{+}, \mathrm{K}^{+}, \mathrm{Mg}^{2+}\right.$, and $\mathrm{Ca}^{2+}$ produced by dissociation of the metal precursors at gasification temperatures) through the pores of the chars. The variations in the activities of the catalysts were also ascribed to differences in the extent of deactivation as a result of the catalysts reaction with inorganic materials in the coal, and to the presence or absence of coal surface metal-oxygen complexes which have been hypothesized as essential prerequisites for coal char reactivity (2-7). It has also been suggested that the metal ion of the catalytic salt reacts with the carbon in the char to form active intermediates for gasification and that the anion of the salt favorably modifies the structure of the active species. However the composition and structure of the active intermediates are unknown (8).

Since coal is normally impregnated with catalyst from solution, the variations in the activities of different catalytic salts of the same metal may be due to the influence of the different catalyst precursor anions during the adsorption of the metal ions onto the coal. The surface charge properties of aqueous suspensions of coal is well known. However, the effects of catalyst precursor anions on coal 
electrokinetic properties, catalyst adsorption, dispersion and activity have not been determined. The goal of this project is to investigate these parameters in relation to catalyzed coal gasification.

\section{EXPERIMENTAL}

The surface electrochemistry of the raw coal (North Dakota Hagel lignite, PSOC 1482) in the presence or absence of acetate or nitrate anions was investigated by dispersing $300 \mathrm{mg}$ of the coal (-200 mesh sieve size) in a liter of distilled water or in a solution containing $10^{-1}, 10^{-2}$ or $10^{-3}$ mol l-1 $\mathrm{CH}_{3} \mathrm{COO}$ - using calcium acetate as the source of $\mathrm{CH}_{3} \mathrm{COO}$. The slurries were divided into $50.0 \mathrm{ml}$ portions and the $\mathrm{pHs}$ were adjusted using nitric acid a few drops of dilute $\mathrm{HNO}_{3}$ or $\mathrm{KOH}$ solution. In the case of $\mathrm{NO}_{3}{ }^{2}$, calcium nitrate was used as the source of the anion and the nitrate concentration ranged from $10^{-6}$ to $10^{-1} \mathrm{~mol} \mathrm{I}^{-1}$. The slurries were mechanically agitated for $3 \mathrm{~h}$ to attain equilibrium after which the $\mathrm{pHs}$ of the slurries were redetermined and the zeta potentials were measured using a "Pen Kem model 501 Lazer Zee Meter."

\section{RESULTS AND DISCUSSION}

The effects of acetate anion $\left(\mathrm{CH}_{3} \mathrm{COO}\right)$ concentration on the zeta potential are compared to that of the parent coal in Figure 1. As evident, the surface charge density of the coal (PSOC 1482) increases progressively as the pH of the slurry is raised from about $\mathrm{pH} 2$ to $\mathrm{pH} 10$. This behavior has been attributed to the dissociation of the coal surface carboxylic and hydroxyl groups, as discussed by several investigators (9-11). Except between $\sim \mathrm{pH} 6.5$ and 10, the surface charge density is essentially similar to that of the coal for $\mathrm{CH}_{3} \mathrm{COO}$ - concentration of $10^{-3}$ 
mol 1-1. However, the coal surface becomes less negatively charge as the acetate anion concentration is raised to $10^{-2}$ or $10^{-1}$ mol $~^{-1}$. In fact, the surface acquires a net positive charge between $\sim \mathrm{pH} 2-4$ for $10^{-1} \mathrm{~mol} \mathrm{I}^{-1} \mathrm{CH}_{3} \mathrm{COO}^{-}$. This phenomenon implies that $\mathrm{Ca}^{2+}$ ion adsorption onto the coal surface increases with increase in the calcium acetate concentration. The adsorption is ascribed to the net negative charge on the coal which favors electrostatic attraction between the surface and the $\mathrm{Ca}^{2}+$ ions. However, the $\mathrm{CH}_{3} \mathrm{COO}$ anions will be repelled by the anionic charge on the coal surface, thus precluding any effects of the $\mathrm{CH}_{3} \mathrm{COO}$ ions on the coal electrokinetic properties.

Figures 2 and 3 show the influence of $\mathrm{NO}_{3}$ - ions on the surface charge of the coals. As in the case of the acetate ion, the zeta potential becomes less negative with increase in the concentration of the $\mathrm{NO}_{3}{ }^{-}$ion. It is however observed that the negative surface charge density becomes substantially reduced for NO3. concentration of 10-3 mol 1-1. A similar behavior was obtained when the pHs of the coal slurries were maintained at $\mathrm{pH} 5.0 \pm 0.4$ and the NO3-concentration was varied (Figure 3). Compared to the effect of the 10-3 mol l-1 acetate concentration, the pronounced reduction in the negative zeta potential in the presence of equivalent nitrate ion concentration may be due to the differences in the sizes and the degree of electrostatic repulsion between the ions and the coal surface.

In the forthcoming quarter, the zeta potential studies as a function of chloride, sulfate, carbonate and nitrate concentration will be continued.

\section{REFERENCES}

1. Calahorro, C.V.; Gonzalez, C.F.; Garcia, A.B.; Serrano, V.G., Fuel 1987, 66, 216.

2. Wigmans, T.; Haringa, H., Moulijn, J. A., Fuel 1983, 62, 185. 
3. Hashimoto, K.; Miura, K.; Xu, J. -J.; Watanabe, A.; Masukami, H. Fuel 1986, 65,489 .

4. Wigmans, T.; van Craneburgh, H.; Elfring, R.; Moulijn, J. A., Carbon 1983, 21, 23.

5. Yuh, S. J.; Wolf, E. E., Fuel 1983, 62, 252.

6. Fredriks, I. L. C.; van Wechem, H,M.H,; Stuiver, J.C.M.; Bouwman, R., Fuel $1981,60,463$.

7. Mims, C. A.; Rose, K. D.; Meichior, M. T.; Pabst, J. K., J. Am. Chem. Soc., $1982,104,6886$.

8. Wood, B. J. and Sancier, K. M. Catal. Rev. Sci. Eng. 1984, 26(2), 233.

9. Abotsi, G. M. K., Bota, K. B., Gautam, S., Am. Chem. Soc., Div. Fuel Chem. Prepr. 1990, 35(3), 606.

10. Quast, K. B.; Readett, D. J., Adv. Coll. Int. Sci. 1987, 27(3-4), 169.

11. Kelebek, S., Salman, T.; Smith, G. W., Canad. Metal. Quart. 1982, 21, 205.

12. Fuerstenau, D. W.; Rosenbaum, J. M.; Laskowski, J., S., Coll. Surf. 1983, \&, 137. 


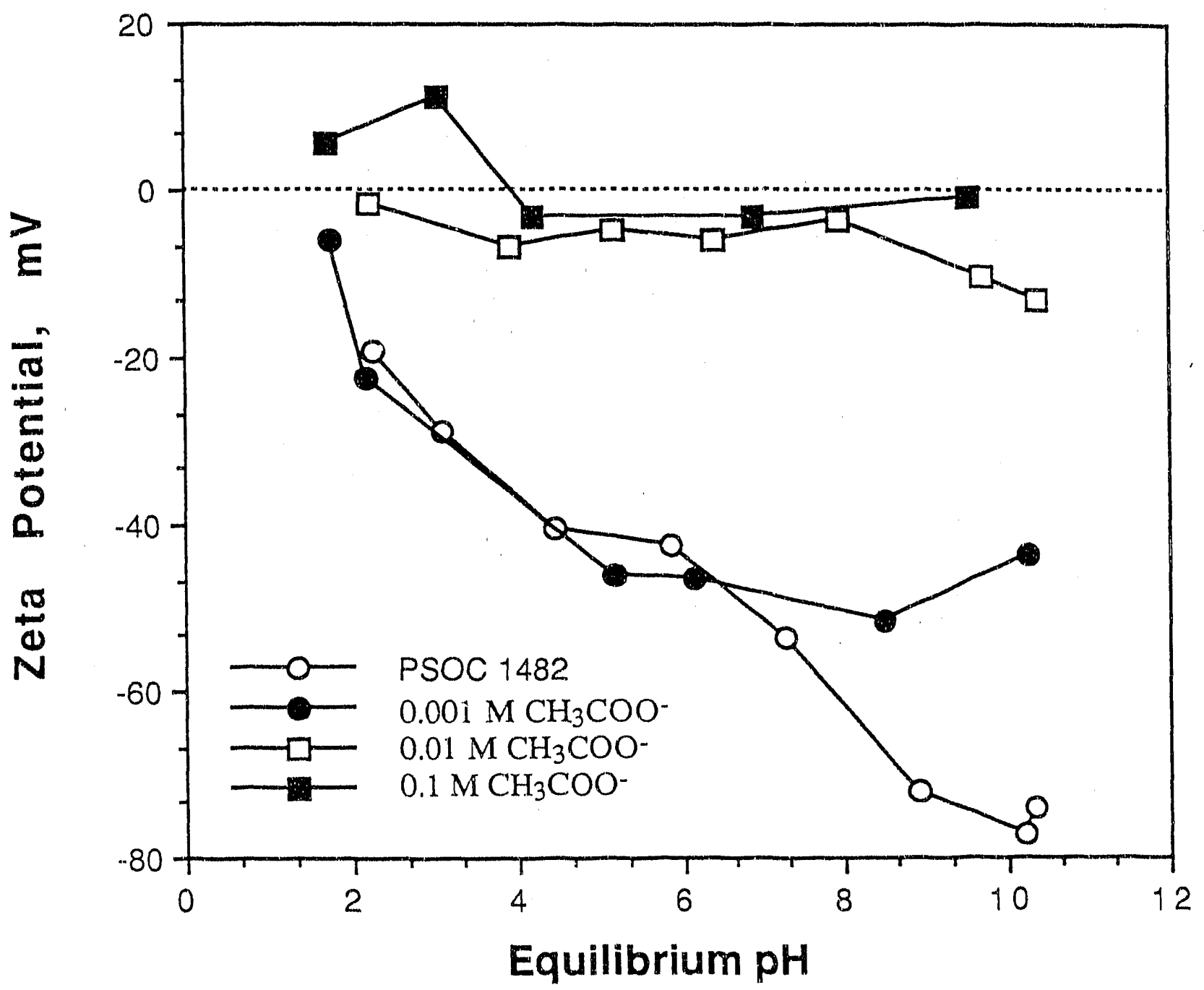

Figure 1. Effects of $\mathrm{pH}$ and Acetate Anion Concentration on the Zeta Potential of North Dakota Hagel Lignite (PSOC 1482). 


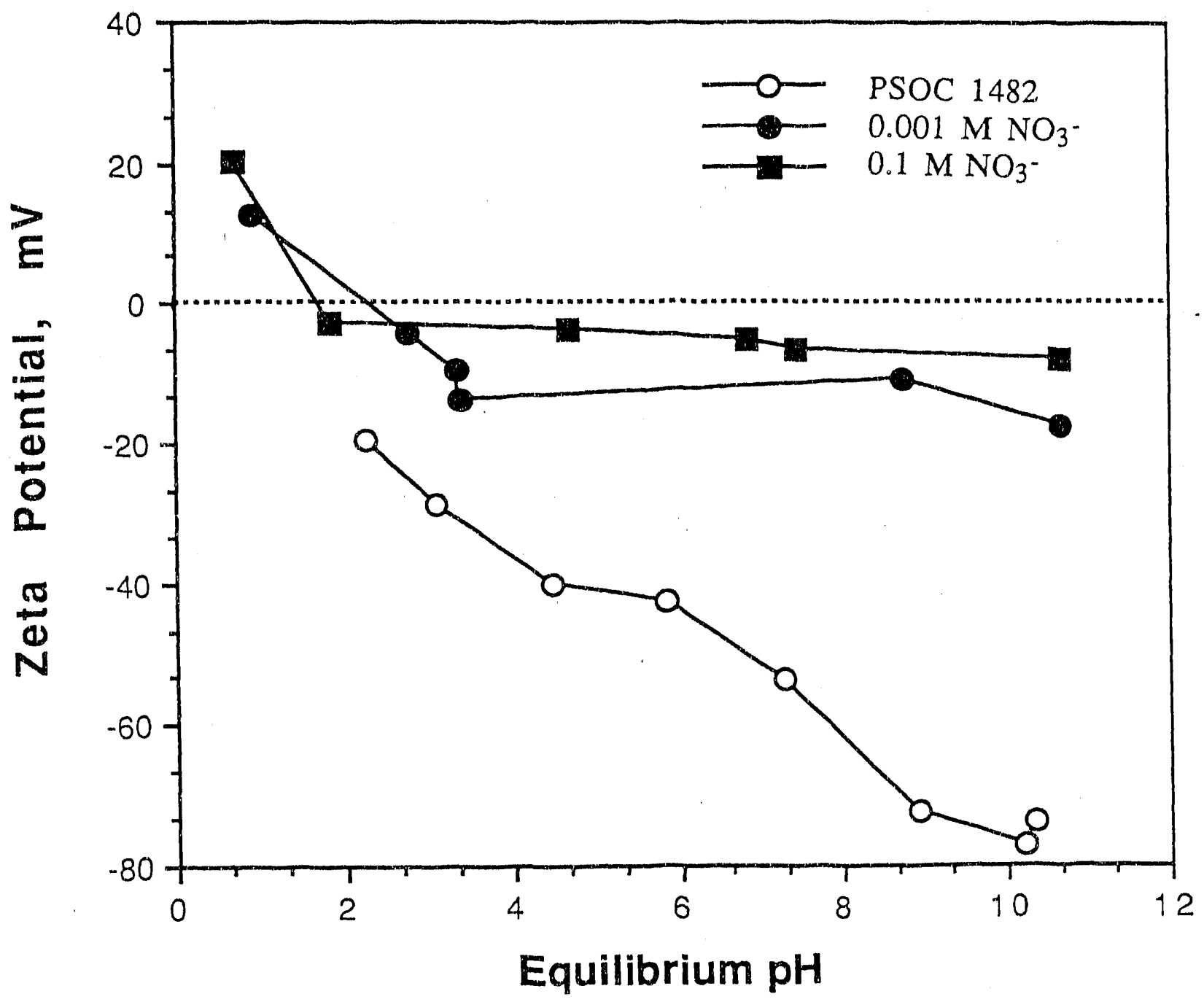

Figure 2. Effects of $\mathrm{pH}$ Variation and Nitrate Anion Concentration on the Zeta Potential of North Dakota Hagel Lignite (PSOC 1482). 


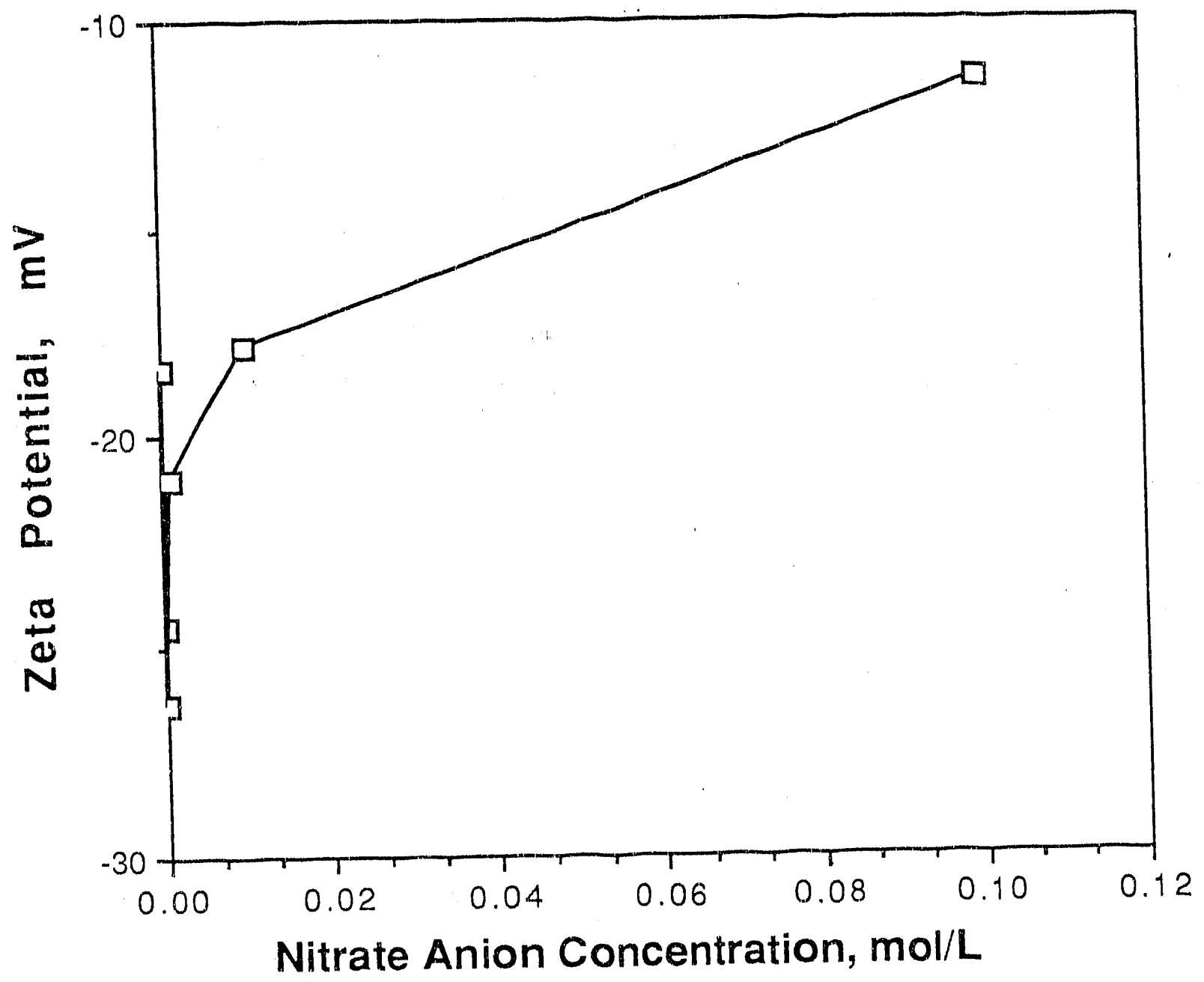

Figure 3. Dependence of Coal (PSOC 1482) Zeta Potential on Nitrate Anion Concentration at a Constant $\mathrm{pH}$ of $5.0 \pm 0.4$. 

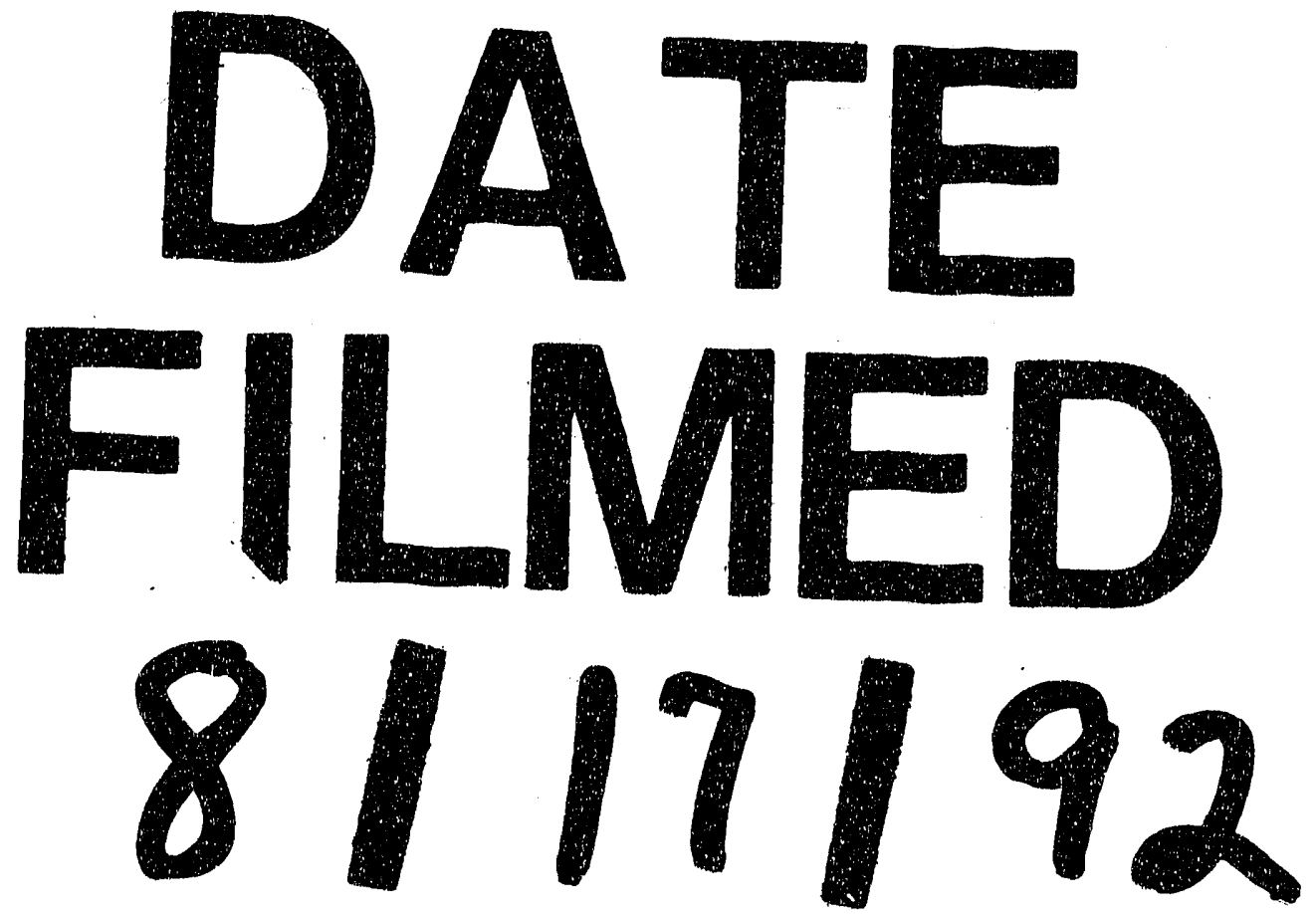


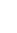

